\title{
Antecedents of Innovation Capability: The Role of Transformational Leadership and Organizational Learning
}

\author{
Nguyen ThiThuy Van ${ }^{1,2}$, Le Ba Phong ${ }^{1,3}$ \& Luu Thi Loan ${ }^{2,4}$ \\ ${ }^{1}$ School of Business Administration, Hunan University, Changsha, China \\ ${ }^{2}$ Saodo University, HaiDuong, Vietnam \\ ${ }^{3}$ Faculty of Business Management, Hanoi University of Industry, BacTuLiem, Hanoi, Vietnam \\ ${ }^{4}$ Faculty of EconomicMmanagement, Beijing Forestry University, China \\ Correspondence: Nguyen ThiThuy Van, School of Business Administration, Hunan University. Lushan South Road, \\ Changsha, Hunan, China.
}

Received: October 27, 2017

Accepted: November 12, 2017

Online Published: August 3, 2018

doi:10.5430/ijba.v9n5p1

URL: https://doi.org/10.5430/ijba.v9n5p1

\begin{abstract}
The paper aims to test the mediating role of organizational learning (OL) between transformational leadership (TL) and innovation. Based on the literature review, we developed a research model proposing that TL enhances innovation capability through its positive effects on four components of OL: Knowledge acquisition, knowledge dissemination, knowledge interpretation, and organization memory. Structural equations modeling (SEM) is applied to examine the influence of independent factors on dependent ones via data collected from 76 Chinese firms. The results indicated that aspects of OL act as the mediators between TL and innovation capability. Especially, the findings highlight the important role of TL practice to enhance OL and the knowledge dissemination's significant impacts on innovation capability. The paper has provided theoretical and managerial initiatives on theory of leadership and innovation that might help firms identify a right pathway to promote their innovation capability aimed at adapting more effectively to the changes of business environment.
\end{abstract}

Keywords: transformational leadership, organizational learning, innovation capability

\section{Introduction}

Innovation has been recognized as an important factor for firms to create value and have a great influence on competition (Mintzberg, 1994). Innovation is fast becoming a crucial factor in firm performance and survival as a result of the evolution of the competitive environment (Wheelwright \& Clark, 1992; Campos \& Pablos, 2004) because it can be a source of competitive advantage (Hinterhuber \& Liozu, 2014). Innovation helps firms adapt well with the uncertainty of the external environment and become one of the most important factors leading to the success of the business in the long term, particularly in the dynamic markets (Baker \& Sinkula, 2002).

Innovation has been defined as the capabilities of creating new ideas or behaviors relating to a system, policy, program, device, process, product or service (Hage, 1999). It is widely accepted as an essential for the survival and growth of organizations (Hurley and Hult, 1998), but many firms do not how to develop it properly (Aragón-Correa et al., 2007). Thus, many studies had been produced to find the effective ways leading to enhancing innovation capability. As a result, researchers have discovered many factors having positive impacts on innovation, such as: organizational culture (Martins \& Terblanche, 2003; Lau \& Ngo, 2004); personal mastery (García-Morales et al., 2007); knowledge inertia (Liao et al., 2008); total quality management (Hung et al., 2011); OL (Liao et al., 2008; García-Morales et al., 2012) and transformational leadership (García-Morales et al., 2012). However, literature on relationship between TL, four specifics components of OL and innovation capability is still sparse and limited. As a result, exploring the mechanism of how the strategic factors like TL and OL positively affecting innovation capability is very necessary by following reasons:

First, innovation capability of an organization is widely considered as a means of enhancing organizational performance however, many firms do not or cannot expand it properly (García Morales et al., 2008). 
Second, Anderson et al. (2014) highlighted the important role of organizational resources and called for the research on the relationship between them and innovation capability. Whereas, OL is viewed as a key organizational resource to create long-term success and competitive advantage for firms (Senge, 1990, Lei et al., 2017). Therefore, exploring of how four specific aspects of OL can foster innovation capability becomes more important.

Finally, although evidence indicated TL practice has a substantial influence on innovation, understanding of the processes through which the transformational leader strives this influence on innovation capability is still limited and largely speculative (García Morales et al., 2008).

Based on such given situation, this study is produced to increase the understanding of how TL affects aspects of OL which in turn leading to innovation capability. Transformational leaders characterizes leaders who stress in communicating about organizational goals in a clear way; proceeding as the leading force; taking part in proactive coaching; encouraging new skill development between employees and unceasingly looking for new opportunities to create the development for their firm (Riggio \& Bass, 2006; Chen et al., 2013; Le \& Lei; 2017). Leadership style is one of the most important individual characters that positively associated with firm innovation as leaders directly decide to bring new ideas into an organization, set specific targets, and encourage innovation initiatives from followers (e.g., McDonough, 2000; Harborne \& Johne, 2003). Although, previous studies indicated that, TL style positively influences OL (Aragón-Correa et al., 2007; García-Morales et al., 2012) which in turn is one of the key antecedents of innovation capability (Calantone et al., 2002; García-Morales et al., 2012). Empirical research on TL, innovation and four specific aspects of OL is still lacking. Thus, this study was produced to address the following research questions: Does TL has significant effect on aspects of OL and innovation? Do aspects of OL mediate between TL and innovation capacity? Which factor has greater influences on the firm's capability for innovation?

To address above questions, we applied structural equation modelling to explore the correlation among the factors based on a survey of 287 participants from 76 manufacturing and service firms in China. By discussing more deeply about the influences of TL on four specific aspects of OL which in turn lead to innovation capability, this study is expected to positively contribute to both practical implication and theoretical initiatives on theory of innovation.

\section{Literature Review and Hypotheses Development}

\subsection{Transformational Leadership and Organizational Learning}

The theory of $\mathrm{OL}$ is increasingly rich, development and attracts a great attention in social scientific research (Bontis et al., 2002; Brockman \& Morgan, 2003; Jiménez-Jiménez \& Sanz-Valle, 2011; Santos-Vijande et al., 2012; Lei et al., 2017). OL helps firms to develop mechanisms and processes which encourage the workplace learning for both individual and group (Armstrong \& Foley, 2003). There are some different interpretations of the OL however much scholar considered OL as a process that includes four basic activities: knowledge acquisition, knowledge dissemination, shared interpretation and organizational memory (Slater \& Narver, 1995; Santos-Vijande et al., 2012; Lei et al., 2017). Knowledge acquisition refers to the process of collecting new information and knowledge from internal and external sources; knowledge dissemination refers to the process of sharing knowledge to all individual and division in the organization; shared interpretation is the process of explaining the significance of the information to create the unity in perception towards the disseminated information; and organizational memory is the process of storing the gathered knowledge and information to ensure meeting the demand of information and knowledge for organization in the future. In general, OL enables individuals and organization to effectively use the wealth of knowledge and awareness to achieve intended goals (Lei et al., 2017).

The positive relation between TL and OL is demonstrated by many authors (Senge et al., 1994; Coad \& Berry, 1998; Bass, 1999; McDonough, 2000; García-Morales et al., 2012). For examples: according Senge et al. (1994), TL might be a catalyst and a facilitator in OL through encouraging shared mental models which stimulates continuous learning and uses of new technologies. Coad and Berry (1998) supposed that, TL fostered OL through promoting intellectual stimulation, inspirational motivation, and self-confidence among organization members. Transformational leaders focus on forming groups, offering them the direction and energy to operate process of OL (Bass, 1999; McDonough, 2000). This way allows firms to learn through experimentation, exploration, communication and dialogue (Slater and Narver, 1995; Lei et al., 2000). As a result, TL becomes one of the most crucial means of developing OL (Slater \& Narver, 1995; Snell, 2001).

Above arguments support positive correlation between TL and OL, to explore deeper the relationship between TL and four aspects of OL, the following hypotheses were posed:

H1a: TL positively impact on knowledge acquisition.

H1b: TL positively impact on knowledge dissemination. 
H1c: TL positively impact on shared interpretation.

H1d: TL positively impact on organizational memory

\subsection{Transformational Leadership and Innovation Capability}

Leaders play a crucial role in generating innovation (Tushman \& Nadler, 1986) and creating a climate that encourages abilities and practices to promote it (Van de Ven, 1986). Characteristics of transformational leaders (including: have charisma, create inspiration, and promote intellectual stimulation) encourage the processes of communication and knowledge that facilitate creativity and innovation for firm (Bass, 1999; Bass \& Avolio, 2000).

Many works in the growing literature on TL have appointed out a positive relationship between TL and innovation (Senge et al., 1994; Aragón-Correa et al., 2007; Sarros et al., 2008; García-Morales et al., 2012). TL is positively associated with innovation capability based on encouraging employees freely in discussing and trying out innovative ideas and approaches (Jung et al., 2003). Transformational leaders create perfect conditions for innovation by forming innovative teams and transmitting stronger motivation to innovate (Tushman \& Nadler, 1986; Senge et al., 1994). They increase innovation capability for firms by stimulating employees to think creatively (Sosik et al., 1997) and motivating them to fulfill duties beyond the expectation (Le \& Lei; 2017).

Based on above argument, we propose following hypothesis.

H2: TL is positively related to innovation quality.

\subsection{Organizational Learning and Innovation Capability}

According to Calantone et al. (2002), OL has a stronger capacity to understand rivals' strengths and weaknesses and thus to learn from their successes and their failures and to generate greater innovative capability than competitors. Literature on the positive correlation between OL and innovation was indicated by many previous researches (Damanpour, 1991; Nonaka \& Takeuchi, 1995; Bontis et al., 2002; Calantone et al., 2002; Dishman \& Pearson, 2003; García-Morales et al., 2012). OL promotes organizational innovation capability (Nonaka \& Takeuchi, 1995; Bontis et al., 2002); supports creativity (Sánchez \& Mahoney, 1996; Yli-Renko et al., 2001), stimulates new knowledge and ideas (Damanpour, 1991; Dishman \& Pearson, 2003), enhances ability to understand and apply these ideas (Damanpour, 1991), favors organizational intelligence and forms a background for orientation to organizational innovation (García-Morales et al., 2012; Yao et al., 2013).

Although the relationship between OL and innovation capability has been empirically tested in details (Calantone et al., 2002; Hall \& Andriani, 2003; Aragón-Correa et al., 2007; García-Morales et al., 2012), few researches examine four specific aspects of OL and innovation quality. To fill in the gaps, we proposed following hypotheses:

H3a: Knowledge acquisition is positively connected with innovation quality.

H3b: Knowledge dissemination is positively connected with innovation quality.

H3c: Shared interpretation is positively connected with innovation quality.

H3a: Organizational memory is positively connected with innovation quality.

Above discussions show that TL positively affect OL, which in turn significant impact on innovation capability. Additionally, prior research showed that OL is the mediator between TL and innovation (García-Morales et al., 2012). We, therefore, proposed that:

H4: OL mediate between TL and innovation capability

\section{Methodology}

\subsection{Sample and Procedure}

This study employs survey method for data collection. Measurement items are adapted from exiting scales in the literature. This study examined a sample of 287 respondents from 76 manufacturing and service firms in Beijing, China. We communicated with the representatives of these firms by phone and/or making personal visits to explain the purpose of the research and ask for their assistance in collecting the questionnaires. The respondents should be team leaders and employees at departments of administration, operation, accounting, marketing and sales to ensure the understanding of the factors in proposal research. We issued 520 questionnaires and received 326 copies, of which 287 was valid (55.2\% validity rate). The Armstrong and Overton (1977) method was used to evaluate potential non-response bias. Chi-square and independent sample $t$-tests were used to compare the first 80 respondents and the last 80 based on demographic variables, such as gender, age and level of education. The results demonstrated there were no significant differences between the two groups of responses $(p>0.05)$. 


\subsection{Measures}

To ensure the validity and reliability of the constructs, this study used items that have been developed and used by previous research. All constructs were measured using multiple items which are measured via five-point Likert-type scales, ranging from " 1 " (strongly disagree) to " 5 " (strongly agree) or from "1" (strongly unwilling to) to 5 (strongly willing to).

$T L$ was measured by four items designed by Podsakoff et al. (1996) for diverse aspects of TL. These scales reflect respondents' perceptions of TL style in their firm. A sample is: "Your firm has leaders who are capable of motivating and guiding their followers on the job". $O L$ was measured by 32 scales developed by Sánchez et al. (2011). These scales reflect four aspects of OL. Samples items are: "We collect and use the information generated during organizational changes."; "Vital information is transmitted quickly to all employees"; "Before a decision is taken the different alternatives are thoroughly analyzed"; and "Key employees when the organization faces a new opportunity or problem can be conveniently contacted". Innovation capability was measured by six scales from Lin (2007). Samples items are: "Our company frequently tries out new ideas" and "Our company is frequently the first to market new products and services".

\section{Data analysis and Results}

\subsection{Measurement Testing}

A series of tests are implemented to evaluate the constructs' reliability and validity for examples: Cronbach's alpha coefficients to test reliability of the measures (Nunnally \& Bernstein, 1994); confirmatory factor analysis (CFA) to test for the convergent validity (Bagozzi and $\mathrm{Yi}, 1988$ ); comparing the squared correlations between the latent variables and square root of average variance extracted (AVE) to test the discriminant validity of measures (Fornell \& Larcker, 1981). Table 1 and Table 2 showed fit indices of the model, suggesting that the relationships among latent constructs fit the data.

Table 1. Standardize loading and reliabilities for measurement model

\begin{tabular}{|c|c|c|c|c|c|}
\hline Construct & Item & Standardize loading & $t$-value & AVE & $\mathrm{C} \alpha$ \\
\hline \multirow[t]{4}{*}{ Transformational leadership } & TL1 & $0.92 * * *$ & 23.9 & 0.80 & 0.94 \\
\hline & TL2 & $0.86 * * *$ & 30.1 & & \\
\hline & TL3 & $0.90 * * *$ & 22.6 & & \\
\hline & TL4 & $0.88 * * *$ & 30.2 & & \\
\hline \multirow[t]{5}{*}{ Knowledge acquisition (KA) } & KA1 & $0.84 * * *$ & 19.5 & 0.74 & 0.97 \\
\hline & KA2 & $0.86^{* * *}$ & 19.1 & & \\
\hline & KA9 & $\begin{array}{c}\cdots \\
088 * * *\end{array}$ & $\ldots$ & & \\
\hline & KA10 & $0.88 * * *$ & $\begin{array}{l}19.0 \\
19.8\end{array}$ & & \\
\hline & KA11 & $0.85 * * *$ & 18.8 & & \\
\hline \multirow[t]{5}{*}{ Knowledge dissemination (KD) } & KD1 & $0.83 * * *$ & 16.1 & 0.66 & 0.93 \\
\hline & $\mathrm{KD} 2$ & $0.78 * * *$ & 16.0 & & \\
\hline & $\ldots$ & $\ldots$ & $\ldots$ & & \\
\hline & KD6 & $0.77 * * *$ & 14.4 & & \\
\hline & KD7 & $0.85 * * *$ & 16.3 & & \\
\hline \multirow[t]{5}{*}{ Shared interpretation (SI) } & SI1 & $0.90 * * *$ & 21.7 & 0.72 & 0.95 \\
\hline & SI2 & $0.86 * * *$ & 19.7 & & \\
\hline & $\ldots$ & $\ldots$ & $\ldots$ & & \\
\hline & SI6 & $0.87 * * *$ & 25.8 & & \\
\hline & SI7 & $0.77 * * *$ & 16.2 & & \\
\hline \multirow[t]{5}{*}{ Organizational memory (OM) } & OM1 & $0.90 * * *$ & 31.0 & 0.74 & 0.95 \\
\hline & OM2 & $0.88 * * *$ & 22.8 & & \\
\hline & $\ldots$ & $\ldots$ & $\ldots$ & & \\
\hline & OM6 & $0.85 * * *$ & 20.8 & & \\
\hline & OM7 & $0.89 * * *$ & 23.5 & & \\
\hline \multirow[t]{6}{*}{ Innovation capability (IC) } & IC1 & $0.95 * * *$ & 32.1 & 0.85 & 0.97 \\
\hline & $\mathrm{IC} 2$ & $0.92 * * *$ & 37.4 & & \\
\hline & IC3 & $0.93 * * *$ & 28.9 & & \\
\hline & IC4 & $0.88 * * *$ & 24.7 & & \\
\hline & IC5 & $0.93 * * *$ & 29.7 & & \\
\hline & IC6 & $0.92 * * *$ & 32.1 & & \\
\hline
\end{tabular}


Table 2. Descriptive statistics and construct correlations

\begin{tabular}{ccccccccc}
\hline Construct & Mean & SD & TL & KA & KD & SI & OM & IC \\
\hline TL & 3,45 & 0.68 & $\mathbf{0 . 8 9}$ & & & & & \\
KA & 3.51 & 0.62 & $0.75^{* * *}$ & $\mathbf{0 . 8 6}$ & & & & \\
KD & 3.57 & 0.58 & $0.78^{* * *}$ & $0.72^{* * *}$ & $\mathbf{0 . 8 1}$ & & & \\
SI & 3.65 & 0.54 & $0.69^{* * *}$ & $0.71^{* * *}$ & $0.66^{* * *}$ & $\mathbf{0 . 8 5}$ & & \\
OM & 3.56 & 0.64 & $0.76^{* * *}$ & $0.73^{* * *}$ & $0.71^{* * *}$ & $0.69^{* * *}$ & $\mathbf{0 . 8 6}$ & \\
IC & 3.83 & 0.71 & $0.74^{* * *}$ & $0.71^{* * *}$ & $0.74^{* * *}$ & $0.70^{* * *}$ & $0.71^{* * *}$ & $\mathbf{0 . 9 2}$ \\
\hline
\end{tabular}

Notes: Diagonal elements (in bold) are the square root of the AVE; Off-diagonal elements are the correlations among constructs; $* * * p<0.001$

\section{Structural equation model and research findings}

The study used SEM with maximum likelihood estimation procedures to test the hypotheses (see Figure 1). Table 3 shows the fit indices of the model. The fit indices of the model is satisfactory

Table 3. Model fit indices for structural model

\begin{tabular}{lrl}
\hline Fit index & Scores & Recommended value \\
\hline Absolute fit measures & & \\
CMIN/df & 1.890 & $\leq 2^{\mathrm{a}} ; \leq 5^{\mathrm{b}}$ \\
GFI & 0.800 & $\geq 0.90^{\mathrm{a}} ; \geq 0.80^{\mathrm{b}}$ \\
RMSEA & 0.056 & $\leq 0.8^{\mathrm{a}} ; \leq 0.10^{\mathrm{b}}$ \\
Incremental fit measures & & \\
NFI & $0.900 \quad \geq 0.90^{\mathrm{a}} ;$ \\
CFI & $0.949 \quad \geq 0.90^{\mathrm{a}} ;$ \\
Notes: a Acceptability: acceptable; $b$ Acceptability: marginal \\
\hline
\end{tabular}

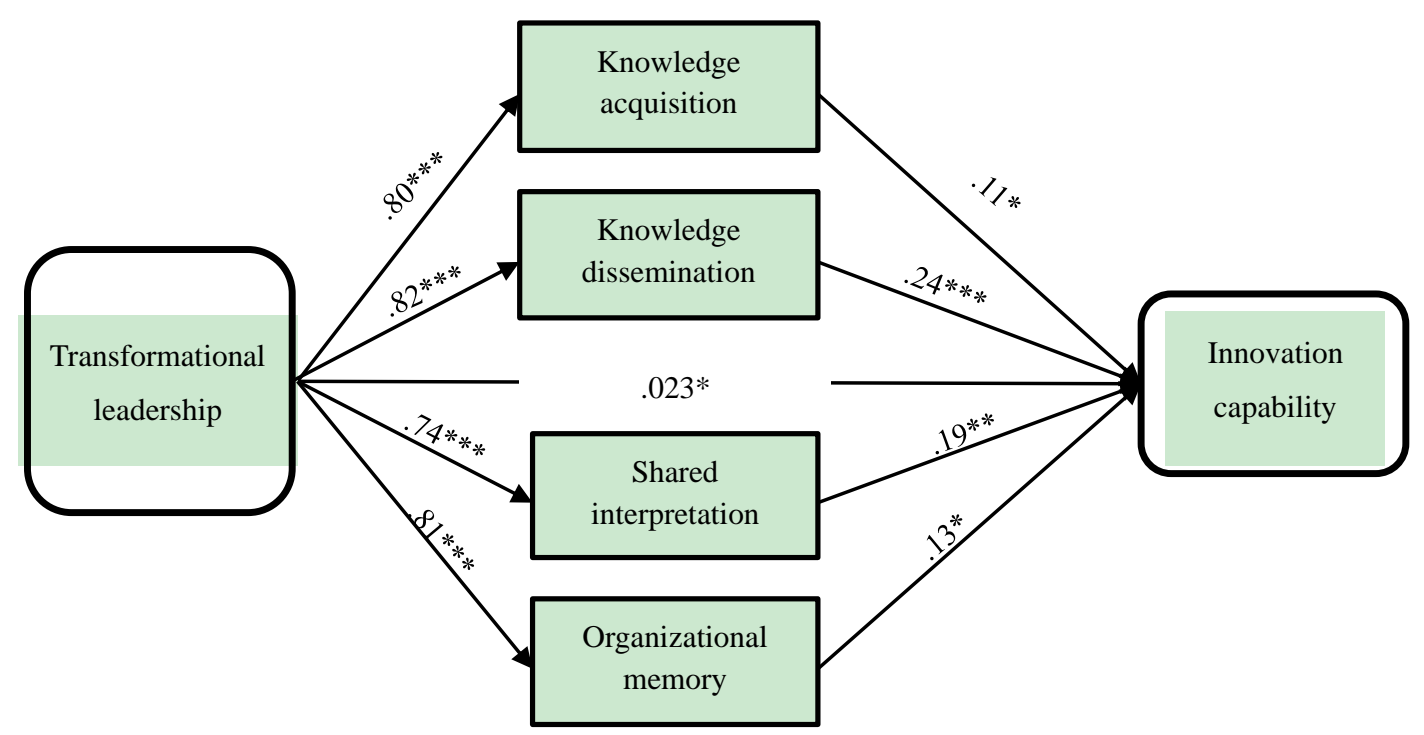

Figure 1. Path coefficients of the structural model

Note: $* * * p<0.001 ; * * p<0.05 ; * p<0.1$ 
Table 4. Structural model results

\begin{tabular}{lccccc}
\hline Effects & Hypothesis & Proposal effect & Estimate & $p$-value & Results \\
\hline TL $\rightarrow$ KA & H1a & + & $0.803^{* * *}$ & $<0.001$ & Supported \\
TL $\rightarrow$ KD & H1b & + & $0.821^{* * *}$ & $<0.001$ & Supported \\
TL $\rightarrow$ SI & H1c & + & $0.7466^{* * *}$ & $<0.001$ & Supported \\
TL $\rightarrow$ OM & H1d & + & $0.811^{* * *}$ & $<0.001$ & Supported \\
TL $\rightarrow$ IC & H2 & + & $0.234^{* * *}$ & 0.08 & Supported \\
KA $\rightarrow$ IC & H3a & + & $0.115^{*}$ & 0.09 & Supported \\
KD $\rightarrow$ IC & H3b & + & $0.249^{* * *}$ & $<0.001$ & Supported \\
S $\rightarrow$ IC & H3c & + & $0.198^{* *}$ & 0.001 & Supported \\
OM $\rightarrow$ IC & H3d & + & $0.133^{*}$ & 0.06 & Supported \\
\hline
\end{tabular}

Notes: $* * * p<0.001 ; * * p<0.05 ; * p<0.1$

\section{Direct effect analysis}

The results (Table 4 and Figure 1) show that direct effects of TL on OL and innovation capability; indirect effect of OL on innovation capability are found to be significant supported hypotheses H1a.b.c.d, H 2, and H3a.b.c.d.

For hypothesis H1a.b.c.d, relating to the TL's effect on aspects of OL. The results showed that, TL has greater effect on knowledge dissemination $(\beta=0.821 ; p<0.001)$ in comparison with its effect on knowledge acquisition $(\beta=$ 0.804; $p<0.001)$, shared interpretation $(\beta=0.746 ; p<0.001)$, and organizational memory $(\beta=0.811 ; p<0.001)$.

Hypothesis $\mathrm{H} 2$ refers to the TL's effect on innovation capability. The result supports the positive effect of TL on innovation capability at $\beta=0.234(p=0.08)$.

The results in Table 4 also support H3a.b.c.d. Specifically the results indicated that, knowledge dissemination has greater effect on innovation capability $(\beta=0.249 ; p<0.001)$ in comparison with the effect of knowledge acquisition $(\beta=0.115 ; p=0.09)$, shared interpretation $(\beta=0.198 ; p=0.001)$, and organizational memory $(\beta=0.133 ; p=0.06)$ on innovation capability.

\section{Indirect and total effect analysis}

Our study does not just give evidence about the influence of TL on innovation; it also shows how this mechanism is activated through OL. To provide evidence on the mediating roles of OL between TL and innovation, further analyses was implemented to verify the magnitude and the statistical significance of the indirect effects. We used the bootstrap confidence intervals method with 5,000 iterations as the suggestion of Preacher and Hayes (2008) to test the significance of indirect effects (see Table 5).

Table 5. Direct, indirect and total effects analysis

\begin{tabular}{|c|c|c|c|c|c|}
\hline \multirow[b]{2}{*}{ Path } & \multirow{2}{*}{$\begin{array}{l}\text { Direct } \\
\text { effects }\end{array}$} & \multirow{2}{*}{$\begin{array}{l}\text { Indirect } \\
\text { effects }\end{array}$} & \multirow{2}{*}{$\begin{array}{l}\text { Total } \\
\text { effects }\end{array}$} & \multicolumn{2}{|c|}{ Bias-corrected confidence intervals } \\
\hline & & & & $\begin{array}{c}\text { Lower } \\
\text { confidence level }\end{array}$ & $\begin{array}{c}\text { Upper } \\
\text { confidence level }\end{array}$ \\
\hline $\mathrm{TL} \rightarrow \mathrm{OL} \rightarrow \mathrm{IC}$ & $0.234 *$ & $0.553 * * *$ & $0.787 * * *$ & 0.393 & 0.718 \\
\hline
\end{tabular}

Note: $* * * p<0.001$

Table 5 showed indirect effects of TL on innovation capability has the coefficient values are 0.553 (which were in confidence intervals) with $p$ value less than 0.001 . Thus, hypothesis $\mathrm{H} 4$ was supported. Table 5 firstly confirms the mediating role of aspects of OL in the relationships between TL and innovation capability.

\section{Discussions and Conclusions}

\subsection{Discussions and Implications}

Firms need to improve their innovation capability because it helps firms to adapt well with the uncertainty of the external environment and it is one of the most important factors leading to the success of the business in the long term (Vrakking, 1990; Balkin et al., 2000; Baker \& Sinkula, 2002). In the context that many Chinese firms invested a lot of resource and effort to improving innovation capability they still get difficult to become innovators (Song, 
2015), hypotheses that were developed in our study significantly contribute to both practical and theoretical initiatives on innovation capability by following key points.

First, many prior researches paid more efforts on exploring the factors which enrich knowledge capital to create competitive advantage for firms (Liao et al., 2007; Le \& Lei, 2017). The empirical findings of this study provide the evidence that TL style might be one of most appropriate factor that increases firm's knowledge capital via its positive effects on knowledge acquisition, knowledge dissemination, shared interpretation and organizational memory. The findings, therefore, highlight the important role of TL practice to develop specific aspect of OL by considering employees as the firm's valuable resource; building emotional links with its followers and inspiring them to higher values; motivating and guiding employees; acting as the organization's leading force.

Second, exploring more deeply the correlation between four specific aspects of OL and innovation capability is the important contribution of this study. The finding indicated that knowledge acquisition, knowledge dissemination, shared interpretation and organizational memory are positively associated with firm's innovation capability, of which, knowledge dissemination is the most significant factor in improving organizational capability for innovation. From this finding, an important implication for managers/leaders is that, to enhancing their firm capability for innovation, they need to focus on activities which positively affect knowledge sharing among employee such as building employee trust in leadership, creating the justice in distributions and procedures (Le \& Lei, 2017). TL practice is also the effective way to promote knowledge dissemination through which to improve innovation capability in an organization.

Third, our study contributes to fill the theoretical gaps by connecting TL, OL and innovation capability in a model. The empirical findings supported the mediating roles of aspects of OL, and underline that TL practice can create significant effects on innovation capability directly or indirectly through improving aspects of OL. As a result, from the finding, our study is expected to increase the understandings as well as the effective and specific way for leaders/managers to improve their firm capability for innovation.

Besides the significant contributions, our study also has some limitations. First, this study use cross-sectional design, so causal relationships may have some differences in other context or may change in the long term, a longitudinal study is needed to overcome this limitation and consolidate the results. Second, this study has not explained the effect mechanism of TL and OL on different aspects of innovation capability such as: product innovation product, process innovation, and managerial innovation. Future researches should continue to evaluate the impact of TL and OL on specific aspects of innovation capability to have full understanding of the relationship between these constructs. Third, this study has not evaluated the relationship between latent variables in case of having the impact of control or moderating variables. So, future researches may explore more deeply the relationship between latent variables in the research model by adding control or moderator variables such as, firm size, firm age and type of industry.

\subsection{Conclusions}

This study has provided empirical evidence to clarify the hypothesis that TL and OL significantly contribute to firm's innovation capability. The findings are encouraged to bring more deeply understanding about the way the leaders/managers might operate their firm to improve four specific aspects of OL and innovation capability by focusing the important role of TL practice.

\section{References}

Anderson, N., Potočnik, K., \& Zhou, J. (2014). Innovation and creativity in organizations: A state-of-the-science review, prospective commentary, and guiding framework. Journal of Management, 40(5), 1297-1333. https://doi.org/10.1177/0149206314527128

Aragón-Correa, J.A., García-Morales, V.J., \& Cordón-Pozo, E. (2007). Leadership and organizational learning's role on innovation and performance: Lessons from Spain. Industrial Marketing Management, 36(3), 349-359. https://doi.org/10.1016/j.indmarman.2005.09.006

Armstrong, A., \& Foley, P. (2003). Foundations for a learning organization: organization learning mechanisms. The Learning Organization, 10(2), 74-82. https://doi.org/10.1108/09696470910462085

Armstrong, J.S., \& Overton, T.S. (1977). Estimating nonresponse bias in mail surveys. Journal of Marketing Research, 14, 396-402. https://doi.org/10.2307/3150783

Bagozzi, R.P., \& Yi, Y. (1988). On the evaluation of structural equation models. Journal of the Academy of Marketing Science, 16(1), 74-94. https://doi.org/10.1007/BF02723327 
Baker, W.E., \& Sinkula, J.M. (2002). Market orientation, learning orientation and product innovation: delving into the organization's black box. Journal of Market-Focused Management, 5(1), 5-23. https://doi.org/10.1023/A:1012543911149

Balkin, D.B., Markman, G.D., \& Gomez-Mejia, L.R. (2000). Is CEO pay in high-technology firms related to innovation? Academy of Management Journal, 43(6), 1118-1129. https://doi.org/10.2307/1556340

Bass, B.M. (1999). Two decades of research and development in transformational leadership. European Journal of Work and Organizational Psychology, 8(1), 9-32. https://doi.org/10.1080/135943299398410

Bass, B.M., \& Avolio, B.J. (2000). MLQ: Multifactor leadership questionnaire: Mind Garden.

Bontis, N., Crossan, M.M., \& Hulland, J. (2002). Managing an organizational learning system by aligning stocks and flows. Journal of Management Studies, 39(4), 437-469. https://doi.org/10.1111/1467-6486.t01-1-00299

Brockman, B.K., \& Morgan, R.M. (2003). The role of existing knowledge in new product innovativeness and performance. Decision Sciences, 34(2), 385-419. https://doi.org/10.1111/1540-5915.02326

Calantone, R.J., Cavusgil, S.T., \& Zhao, Y. (2002). Learning orientation, firm innovation capability, and firm $\begin{array}{llll}\text { performance. Industrial } & \text { Marketing }\end{array}$ https://doi.org/10.1016/S0019-8501(01)00203-6

Campos, E.B., \& de Pablos, P.O. (2004). Innovation and learning in the knowledge-based economy: challenges for the firm. International Journal of Technology Management, 27(6), 531-532.

Coad, A.F., \& Berry, A.J. (1998). Transformational leadership and learning orientation. Leadership \& Organization Development Journal, 19(3), 164-172. https://doi.org/10.1108/01437739810210211

Chen, Y., Jermias, J., \& Lee, G. (2013). The Performance Implication of Goal Achievability in Incentive Contracts and Feedback. Paper presented at the CAAA Annual Conference.

Damanpour, F. (1991). Organizational innovation: A meta-analysis of effects of determinants and moderators. Academy of Management Journal, 34(3), 555-590. https://doi.org/10.2307/256406

Dishman, P., \& Pearson, T. (2003). Assessing intelligence as learning within an industrial marketing group: A pilot study. Industrial Marketing Management, 32(7), 615-620. https://doi.org/10.1016/S0019-8501(03)00030-0

Fornell, C., \& Larcker, D.F. (1981). Evaluating structural equation models with unobservable variables and measurement error. Journal of Marketing Research, 18(1), 39-50. https://doi.org/10.2307/3151312

García-Morales, V.J., Jiménez-Barrionuevo, M.M., \& Gutiérrez-Gutiérrez, L. (2012). Transformational leadership influence on organizational performance through organizational learning and innovation. Journal of Business Research, 65(7), 1040-1050. https://doi.org/10.1016/j.jbusres.2011.03.005

García-Morales, V.J., Lloréns-Montes, F.J., \& Verdú-Jover, A.J. (2007). Influence of personal mastery on organizational performance through organizational learning and innovation in large firms and SMEs. Technovation, 27(9), 547-568. https://doi.org/10.1016/j.technovation.2007.02.013

Hage, J.T. (1999). Organizational innovation and organizational change. Annual Review of Sociology, 597-622. https://doi.org/10.1146/annurev.soc.25.1.597

Hall, R., \& Andriani, P. (2003). Managing knowledge associated with innovation. Journal of Business Research, 56(2), 145-152. https://doi.org/10.1016/S0148-2963(01)00287-9

Harborne, P., \& Johne, A. (2003). Creating a project climate for successful product innovation. European Journal of Innovation Management, 6(2), 118-132. https://doi.org/10.1108/14601060310475273

Hinterhuber, A., \& Liozu, S.M. (2014). Is innovation in pricing your next source of competitive advantage? Business Horizons, 57(3), 413-423. https://doi.org/10.1016/j.bushor.2014.01.002

Hung, R.Y.Y., Lien, B.Y.H., Yang, B., Wu, C.M., \& Kuo, Y.M. (2011). Impact of TQM and organizational learning on innovation performance in the high-tech industry. International Business Review, 20(2), 213-225. https://doi.org/10.1016/j.ibusrev.2010.07.001

Jiménez-Jiménez, D., \& Sanz-Valle, R. (2011). Innovation, organizational learning, and performance. Journal of Business Research, 64(4), 408-417. https://doi.org/10.1016/j.jbusres.2010.09.010 
Jung, D.I., Chow, C., \& Wu, A. (2003). The role of transformational leadership in enhancing organizational innovation: Hypotheses and some preliminary findings. The Leadership Quarterly, 14(4), 525-544. https://doi.org/10.1016/S1048-9843(03)00050-X

Lau, C.M., \& Ngo, H.Y. (2004). The HR system, organizational culture, and product innovation. International Business Review, 13(6), 685-703. https://doi.org/10.1016/j.ibusrev.2004.08.001

Le, P.B., \& Lei, H. (2017). How transformational leadership supports knowledge sharing: Evidence from Chinese manufacturing and service firms. Chinese Management Studies, 11(3), 479-497. https://doi.org/10.1108/CMS-02-2017-0039

Lei, H., Le, P.B., \& Nguyen, H.T.H. (2017). How Collaborative Culture Supports for Competitive Advantage: The Mediating Role of Organizational Learning. International Journal of Business Administration, 8(2), 73. https://doi.org/10.5430/ijba.v8n2p73

Liao, S.H., Fei, W.C., \& Chen, C.C. (2007). Knowledge sharing, absorptive capacity, and innovation capability: an empirical study of Taiwan's knowledge-intensive industries. Journal of Information Science, 33(3), 340-359. https://doi.org/10.1177/0165551506070739

Liao, S.H., Fei, W.C., \& Liu, C.T. (2008). Relationships between knowledge inertia, organizational learning and organization innovation. Technovation, 28(4), 183-195. https://doi.org/10.1016/j.technovation.2007.11.005

Lin, H.F. (2007). Knowledge sharing and firm innovation capability: an empirical study. International Journal of Manpower, 28(3/4), 315-332. https://doi.org/10.1108/01437720710755272

Martins, E., \& Terblanche, F. (2003). Building organisational culture that stimulates creativity and innovation. European Journal of Innovation Management, 6(1), 64-74. https://doi.org/10.1108/14601060310456337

McDonough, E.F. (2000). Investigation of factors contributing to the success of cross-functional teams. Journal of Product Innovation Management, 17(3), 221-235. https://doi.org/10.1111/1540-5885.1730221

Mintzberg, H. (1994). The rise and fall of strategic planning: Preconceiving roles for planning, plans, planners. New York, 221-321.

Nonaka, I., \& Takeuchi, H. (1995). The knowledge-creating company: How Japanese companies create the dynamics of innovation. Oxford university press.

Nunnally, J.C., \& Bernstein, I. (1994). Elements of statistical description and estimation (3rd ed.). Psychometric Theory (Edited by: Nunnally JC, Bernstein IH).

Podsakoff, P.M., MacKenzie, S.B., \& Bommer, W.H. (1996). Transformational leader behaviors and substitutes for leadership as determinants of employee satisfaction, commitment, trust, and organizational citizenship behaviors. Journal of Management, 22(2), 259-298. https://doi.org/10.1177/014920639602200204

Preacher, K.J., \& Hayes, A.F. (2008). Asymptotic and resampling strategies for assessing and comparing indirect effects in multiple mediator models. Behavior Research Methods, 40(3), 879-891. https://doi.org/10.3758/BRM.40.3.879

Riggio, R.E., \& Bass, B. (2006). Transformational leadership. L. Erlbaum Associates.

Sanchez, R., \& Mahoney, J.T. (1996). Modularity, flexibility, and knowledge management in product and organization design. Strategic Management Journal, 17(S2), 63-76. https://doi.org/10.1002/smj.4250171107

Santos-Vijande, M.L., López-Sánchez, J.Á., \& Trespalacios, J.A. (2012). How organizational learning affects a firm's flexibility, competitive strategy, and performance. Journal of Business Research, 65(8), 1079-1089. https://doi.org/10.1016/j.jbusres.2011.09.002

Sarros, J.C., Cooper, B.K., \& Santora, J.C. (2008). Building a climate for innovation through transformational leadership and organizational culture. Journal of Leadership \& Organizational Studies, 15(2), 145-158. https://doi.org/10.1177/1548051808324100

Senge, P. (1990). The fifth discipline: The art and practice of organizational learning. New York.

Senge, P., Roberts, C., Ross, R., Smith, B., \& Kleiner, A. (1994). The Fifth Discipline FieldbookDoubleday. New York.

Slater, S., \& Narver, J. (1995). Market orientation and the learning organisation. Journal of Marketing, 59(3), 63-74. https://doi.org/10.2307/1252120 
Snell, R.S. (2001). Moral foundations of the learning organization. Human Relations, 54(3), 319-342. https://doi.org/10.1177/0018726701543003

Song, Z.H. (2015). Organizational learning, absorptive capacity, imitation and innovation: Empirical analyses of 115 firms across China. Chinese Management Studies, 9(1), 97-113. https://doi.org/10.1108/CMS-05-2014-0092

Sosik, J.J., Avolio, B.J., \& Kahai, S.S. (1997). Effects of leadership style and anonymity on group potency and effectiveness in a group decision support system environment. Journal of Applied Psychology, 82(1), 89. https://doi.org/10.1037/0021-9010.82.1.89

Tushman, M., \& Nadler, D. (1986). Organizing for innovation. California Management Review, 28(3), 74-92. https://doi.org/10.2307/41165203

Van de Ven, A.H. (1986). Central problems in the management of innovation. Management Science, 32(5), 590-607. https://doi.org/10.1287/mnsc.32.5.590

Vrakking, W.J. (1990). The innovative organization. Long Range Planning, 23(2), 94-102. https://doi.org/10.1016/0024-6301(90)90204-H

Wheelwright, S.C., \& Clark, K.B. (1992). Revolutionizing product development: quantum leaps in speed, efficiency, and quality. Simon and Schuster.

Yao, Z., Yang, Z., Fisher, G.J., Ma, C., \& Fang, E.E. (2013). Knowledge complementarity, knowledge absorption effectiveness, and new product performance: The exploration of international joint ventures in China. International Business Review, 22(1), 216-227. https://doi.org/10.1016/j.ibusrev.2012.04.002

Yli-Renko, H., Autio, E., \& Sapienza, H.J. (2001). Social capital, knowledge acquisition, and knowledge exploitation in young technology-based firms. Strategic Management Journal, 22(6-7), 587-613. https://doi.org/10.1002/smj.183 